\title{
LAZULI BUNTING NESTING AT MOOSE JAW
}

By NANCY DUNN, Moose Jaw

This summer a pair of Lazuli untings did us the honour of build$\mathrm{ig}$ their home in our garden above Ioose Jaw Creek. Our yard is large nd contains many fruit trees. The est was built in a six foot pear ee, and here a very friendly little amily of three was raised.

The father was streamlined and bout six inches long. He was cloth$d$ in the most magnificent delhinium-blue coat (rich turquoise), le breast was a dull coral, the wings ad prominent white stripes across hem.

We had great difficulty in disnguishing the mother as she looked ke one of our own sparrows. Howver, when she was on the nest the hite wing-stripes ( $\mathrm{just}$ like ther's) could be readily seen. She ecame very friendly and allowed e to poke my nose two feet from er daily on my morning visit and hat, remaining on the nest all the me.

Her small deep nest was placed at $y$ eye level about five feet from e ground. It contained three chalkhite eggs and one egg which was luish with spots. This egg did not atch. The babies were small editions our sparrows. They were very ucy and they scolded me with a arsh little chirp of a most disgusted ne.

I first noticed these birds when accidentally discovered their nest. he delphiniums were then about ur feet high so this must have been pout the end of June. I watched the mily with interest then until they ft my yard about the end of Augusit. thers to see the birds were $\mathrm{Mr}$. and irs. W. G. Davies and their children, iss N. N. Steele, Miss Hazel Wilrd, Mr. and Mrs. J. E. Seed and y husband, R. J. Dunn.

The little nest is still in the pear ee and reminds me of my friends, e Lazuli Buntings. Because their hirp is distinctive I know that they ave nested here before and I am oking forward to having them nest ere again.

Note: The note sent in by Mrs. unn is an acceptable record of a latively uncommon Saskatchewan rd. Museum records of Lazuli Bunngs in Saskatchewan include ones om Indian Head (two specimen re- cords, May 24, 1890 and one specimen record, May 26, 1892-George W. Lang), Eastend (sight record, July 1 and July 2, 1908 by L. B. Potter; sight record, 1940, L. B. Potter), Broadview (specimen record, May 26, 1931 by F. G. Bard), Dollard (specimen record, 1934; specimen record, May 30, 1934; and sight record, May 31, 1934-all by C. F. Holmes), Regina (sight record, July 11, 1934, by F. G. Bard; sight record Nov., 1935 by Hugh Knowles; sight record May 30, 1947 by Lyle Ehmans), Arcola (sight record July 13, 1938).

For a revision of Mitchell's Checklist of Saskatchewan Birds, 1924, which must soon be undertaken, only the following kinds of records will be accepted: (1) specimen records, (2) photographic records, and (3) well authenticated sight observations by several individuals. Although records must fall into one of these categories before they can be accepted for the preparation of a checklist, other records make quite legitimate reports for submission to the BLUE JAY or to the Museum. A series of such reports helps to establish the distribution of a species. We request your assistance in bringing your observations to our attention. If you report to the BLUE JAY or to the Museum, the results of your field studies will be preserved for future workers. Fred G. Bard, Sask. Museum of Natural History

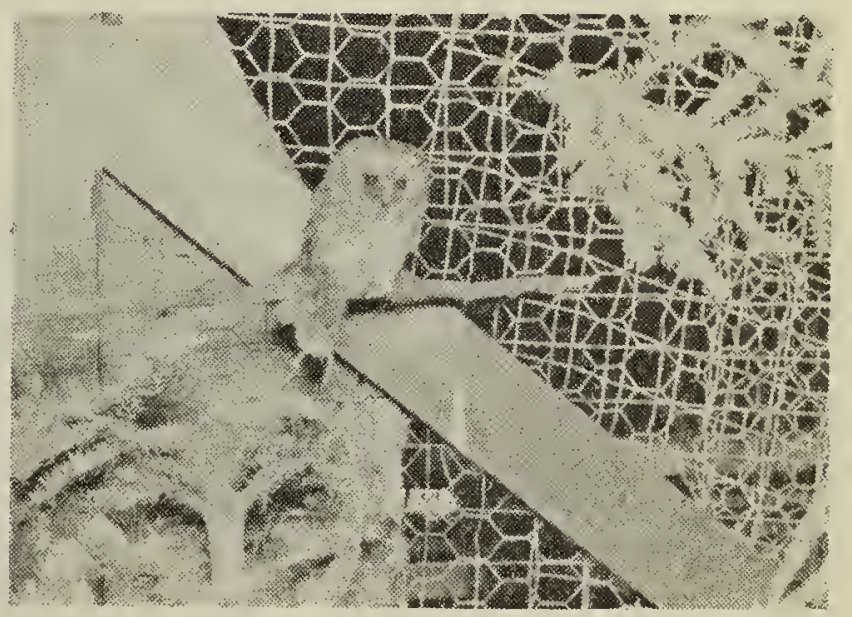

REQUEST FOR NESTING RECORDS OF SAW-WHET OWL - Richard Lumsden of 12026-104th Street, Edmonton, who took this photograph of the little Saw-whet Owl, would like to know of localities where Sawwhet Owls have nested recently (1955-57) within a 100-mile radius of Edmonton. He is eager to locate and photograph these beautiful little "night-pipers" of the spruce groves. 